\title{
Impacts of long-term disturbance on soil health with relation to vegetation distribution in a tropical ecosystem
}

\author{
C. N. Basweti*, S. Otor and S. Manohar \\ Department of Environmental Sciences, Kenyatta University, P.O. Box 43844-00100, Nairobi, Kenya \\ *Corresponding Author: cbasweti@gmail.com
}

\begin{abstract}
Land-use and land-cover changes are the main cause of soil degradation and associated human and environmental problems. The study was conducted in Mai Mahiu ecosystem, Kenya whose aim was to assess long-term (1985 to 2015) impacts of land-use and land-cover changes on soil health with disturbance-induced vegetation distribution. Landsat archive was utilized to detect land-use change for 30 years at an interval of 15 years and analysed based on supervised image classification. Four land-use practices (undisturbed forest, disturbed forest, cropland and grassland) were selected and soil sampled to $15 \mathrm{~cm}$ depth for soil analyses. In this period, cropland increased by $135 \%$ at the expense of natural forest while built-up areas increased by three times. Soil bulk density increased significantly $(\mathrm{p}<0.001)$ from $0.93 \pm 0.02 \mathrm{~g} \mathrm{~cm}^{-3}$ in forest soil to $1.27 \pm 0.02 \mathrm{~g} \mathrm{~cm}^{-3}$ in disturbed grassland. Soil $\mathrm{pH}$ had significant change $(\mathrm{p}=0.002)$ that ranged between $6.19 \pm 0.14$ and $7.18 \pm 0.12$. Soil organic carbon declined significantly ( $\mathrm{p}=0.008$ ) with land-use change with losses of up to $63 \%$ recorded in disturbed grassland. Total nitrogen levels declined from $0.34 \%$ in the forest to $0.15 \%$ in disturbed grassland soil. The pronounced changes in land-use and land-cover in Mai Mahiu have negatively affected the soil health with a potential drop in soil productivity and ecosystem provisioning. An integrated approach, enforcement of relevant laws and policy implementation are recommended to restoring and maintaining soil quality of this ecosystem.
\end{abstract}

Keywords: Land-use, Land-cover, Soil health, Mai Mahiu ecosystem, Kenya.

\section{INTRODUCTION}

Anthropogenic land-use/cover changes are the major cause of soil degradation which has adversely affected ecosystems productivity and wellbeing of the global population. This is due to unsustainable, exploitative and intensification of land-use to satisfy needs for food, energy, feed, fibre and infrastructure development for the rapidly growing population (Lambin et al., 2006; Ellis, 2010) that have led to alteration of 70\% of global land (FAO, 2015; IPCC, 2018) leading to reduction and continued disturbance of forested areas, native grasslands and wetlands (Bahn $e t$ al., 2006). The practice has led to soil degradation through accelerated soil erosion processes thus affecting soil quality which is a vital component of ecosystems and earth system functions that support the delivery of primary ecosystem services (Keesstra et al., 2016) and human wellbeing especially in the under-developing tropical and sub-tropical nations of Africa, Asia, Latin America and the Caribbean.

In the sub-Saharan Africa land use and cover, changes have led to removal of top fertile soil layer (Lal, 2003; Symeonakis et al., 2007; Onur et al., 2009; Ries, 2010) that has resulted to the decline in agricultural productivity (Bationo et al., 2004), decline and/or loss of biological diversity, water quality and quantity, climatic variability, droughts, floods, crop failure and off-site effects. This has made the international community get more concerned about rapid environmental change associated with land-use and land-cover change (Braimoh \& Osaki, 2010).

The Mai Mahiu ecosystem is an important ecological area since it consists of a great portion of the upper Ewaso Kedong water catchment that supports many livelihoods and drains into ecologically sensitive Lake Magadi. Over the last forty years, the area has experienced rapid population growth which is associated with in-migration influenced by social and economic factors. The changes have led to changes in vegetation distribution. The unsustainable land-use practices were believed to have brought degradation subsequently compromising the resilience and productivity of the ecosystem. It has become an important issue in sustainable development that requires an integrated assessment of the environment to understand the nature and extent of problems and come up with mitigation measures. To achieve sustainable development, timely, accurate and current information about land-use and land-cover change is extremely important for proper planning (Lambin \& Geist, 2007; Anil et al., 2011).

This study sought to assess the extent and nature of land-use/cover changes and their impacts on soil health under disturbance-induced vegetation distribution in the area. There is no detailed research that has been carried out in this ecosystem, therefore; limited data exist that can be used for planning for effective protection and restoration of a disturbed ecosystem. 


\section{MATERIALS AND METHODS}

\section{Study area}

The study was conducted in Mai Mahiu situated at latitude between $0^{\circ} 56^{\prime} 0^{\prime \prime} \mathrm{S}$ and $1^{\circ} 2^{\prime} 0^{\prime \prime} \mathrm{S}$, longitude between $36^{\circ}$ $30^{\prime} 0^{\prime \prime} \mathrm{E}$ and $36^{\circ} 36^{\prime} 0^{\prime \prime} \mathrm{E}$ and elevation of $1832 \mathrm{~m}$ above sea level in Naivasha sub-county, Kenya (Fig. 1). The area receives mean total annual rainfall of $800 \mathrm{~mm}$ distributed bimodally where long rain season starts in March and ends in May and the short rain season as from October to December. The annual minimum temperature ranges between $15.9^{\circ} \mathrm{C}$ and $17.8^{\circ} \mathrm{C}$ with a mean of $16.8^{\circ} \mathrm{C}$ while the annual maximum temperature range is between $24.6^{\circ} \mathrm{C}$ and $29.3^{\circ} \mathrm{C}$ with a mean of $27.0^{\circ} \mathrm{C}$. Soils are predominantly Nitosols with a mixture of Andosols, Cambisols and the Regosols. Vegetation is dominated by savannah-type woodlands and grassland formations that are characterized by closed and open shrubs amidst isolated trees. Dominant vegetation includes Acacia xanthophloea (Benth.) that covers open grassland; Euphorbia inaequilatera Sond., Euphorbia candelabrum (Kotschy) and scrub mainly Felicia muricata Thunb., Tarchonanthus camphorantus L. and Rhus natalensis Bernh.

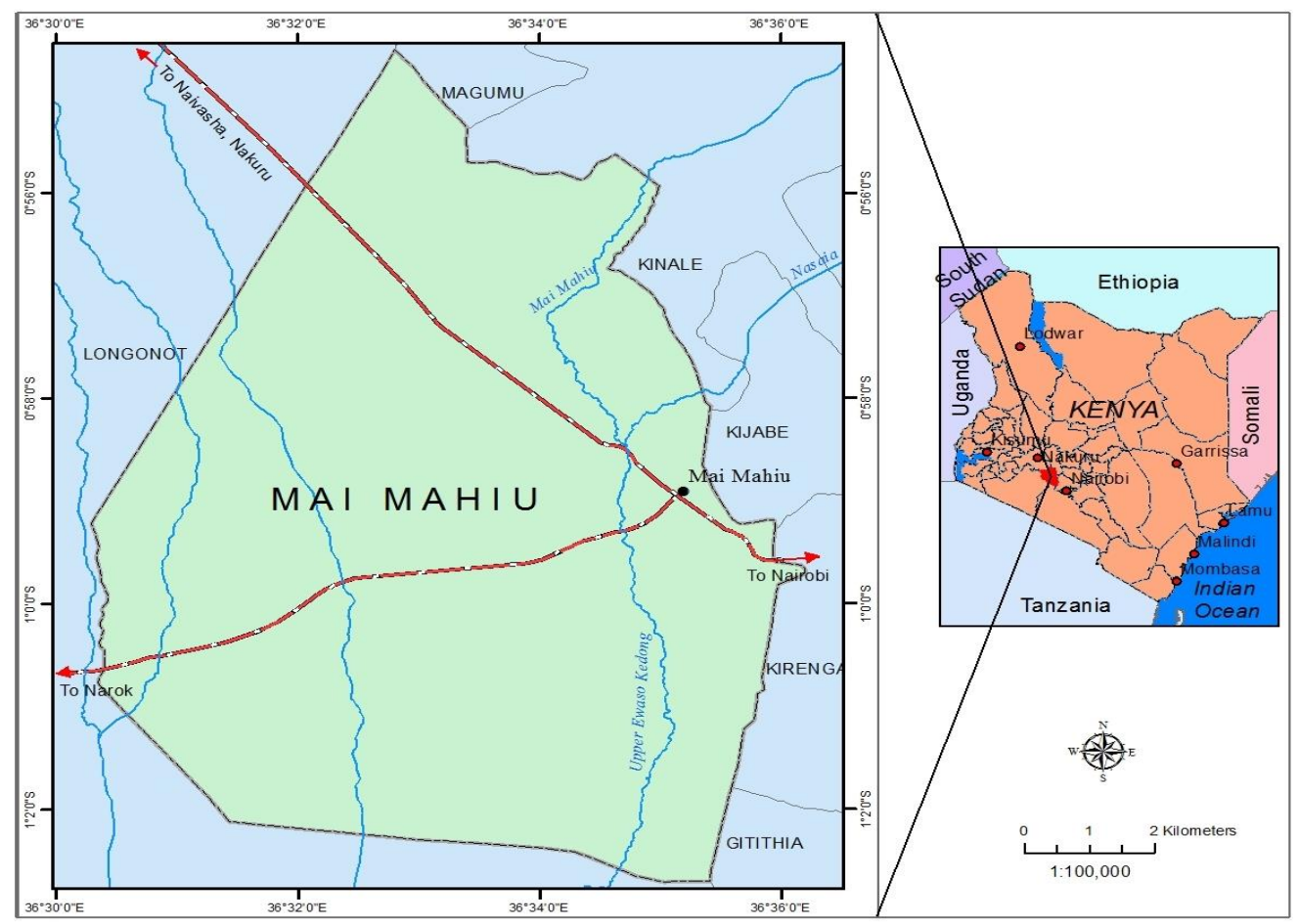

Figure 1. Map of Kenya showing Mai Mahiu (Study area).

\section{Land-use and land-cover change analysis}

The Landsat archive was utilized in the land-use/cover change analysis. Images were acquired from the Global Visualization Viewer (Glovis) archive. The images were at 15 years interval from 1985 to 2015 (Table 1) with cloud cover ranged from 0.34 to $5 \%$ leaving $95 \%$ of pixels in the majority of the scenes usable for further procedures. One Landsat scene covered an area of $250 \mathrm{~km}^{2}$ and the images were taken after every 16 days in different rows and columns to determine changes within this period. The Maximum Likelihood Classification was applied to capture the spectral information of land cover classes. Sampling points which act as the ground truth sites were captured from the field by the GPS which was applied in accuracy assessment on image classification.

Table 1. Dates and scene ID of the Landsat Images used over the study period.

\begin{tabular}{llll}
\hline Year & Day and Month & Path/Row & Entity Id \\
\hline 1985 & $18 / \mathrm{Jan}$ & $168 / 061$ & LT05_L1TP_168061_19850118_20170219_01_T1 \\
2000 & $21 / \mathrm{Feb}$ & $168 / 061$ & LE71680612000052EDC00 \\
2015 & $03 / \mathrm{Feb}$ & $168 / 061$ & LC08_L1TP_168061_20150203_20170426_01_T1 \\
\hline
\end{tabular}

\section{Soil sampling}

Soil samples were collected from four land use and land cover (LULC) types namely: native forest, disturbed forest dominated by Tarchonanthus camphoranthus L., disturbed forest dominated by croton spp., cropland and severely grazed field to $15 \mathrm{~cm}$ depth using soil auger and cylindrical core rings. Soil samples were air-dried and sieved through a $2 \mathrm{~mm}$ mesh. Soil particle size fractions were determined by the hydrometer method (Bouyoucous, 1951), dry bulk density by the core method (Blake, 1965), soil pH by a pH meter (Rhoades, 1996), soil organic carbon (SOC) by the Walkley-Black method (Black, 1965) while total nitrogen (TN) was determined by Kjeldahl method (Bremner, 1996). 


\section{Data analysis}

Soil data from the four land-use modifications/conversions were analysed and compared with native forest soils to detect changes that have taken place. Analysis of variance (ANOVA) was used to detect significant differences ( $\mathrm{p}=$ 0.05 ) in the soil attributes across land use/cover types in Genstat $15^{\text {th }}$ edition (Payne et al., 2012). A least significant difference (LSD) was used for mean separation.

\section{RESULTS AND DISCUSSION}

Land-use and land-cover clusters in 1985 showed thorny shrubs covering an area of $120.3 \mathrm{~km} 2(34 \%)$ and heathland which covered an area of $68.2 \mathrm{~km}^{2}(19 \%)$ while the evergreen trees occupied $35 \mathrm{~km}^{2}(10 \%)$ of the study area. The least land coverage was observed on the cropland (8\%), deciduous trees $(4 \%)$ and the built-up area (3\%). Natural vegetation had not been cleared in 1985 (Table 2). The human activities were minimal in the study area which most likely explains the reason why there is relatively minimal land coverage of built-up areas, disturbed soils, roads, croplands, and bareland.

Table 2. Land-use and land-cover in Mai Mahiu in 1985, 2000 and 2015.

\begin{tabular}{lrrrrrr}
\hline \multirow{2}{*}{ Land-use/cover type } & \multicolumn{2}{c}{$\mathbf{1 9 8 5}$} & \multicolumn{2}{c}{$\mathbf{2 0 0 0}$} & \multicolumn{2}{c}{$\mathbf{2 0 1 5}$} \\
\cline { 2 - 7 } & Area $\left.\mathbf{( k m}^{\mathbf{2}}\right)$ & Coverage (\%) & Area $\left.\mathbf{( k m}^{\mathbf{2}}\right)$ & Coverage (\%) & Area (km $\left.\mathbf{( k m}^{\mathbf{2}}\right)$ & Coverage (\%) \\
\hline Deciduous trees & 15.7 & $4 \%$ & 20.9 & $6 \%$ & 25.3 & $7 \%$ \\
Grassland & 49.6 & $14 \%$ & 35.1 & $10 \%$ & 30.9 & $9 \%$ \\
Bare land & 29.0 & $8 \%$ & 53.7 & $15 \%$ & 34.1 & $10 \%$ \\
Roads/Built-up/soils & 9.8 & $3 \%$ & 19.9 & $6 \%$ & 29.9 & $8 \%$ \\
Evergreen Trees & 35.0 & $10 \%$ & 28.2 & $8 \%$ & 48.8 & $14 \%$ \\
Thorny Shrubs & 120.3 & $34 \%$ & 79.6 & $22 \%$ & 67.0 & $19 \%$ \\
Heathland & 68.2 & $19 \%$ & 37.9 & $11 \%$ & 54.8 & $15 \%$ \\
Cropland & 27.3 & $8 \%$ & 79.6 & $22 \%$ & 64.2 & $18 \%$ \\
\hline Grand Total Area $\left.\mathbf{( k m}^{2}\right)$ & $\mathbf{3 5 4 . 9}$ & $\mathbf{1 0 0 \%}$ & $\mathbf{3 5 4 . 9}$ & $\mathbf{1 0 0 \%}$ & $\mathbf{3 5 4 . 9}$ & $\mathbf{1 0 0 \%}$ \\
\hline
\end{tabular}

The major part is covered with thorny shrubs and heathland which stretch from Mt. Longonot in the north-western part to south respectively. Croplands and also the built-up areas are not pronounced in the area (Fig. 2).

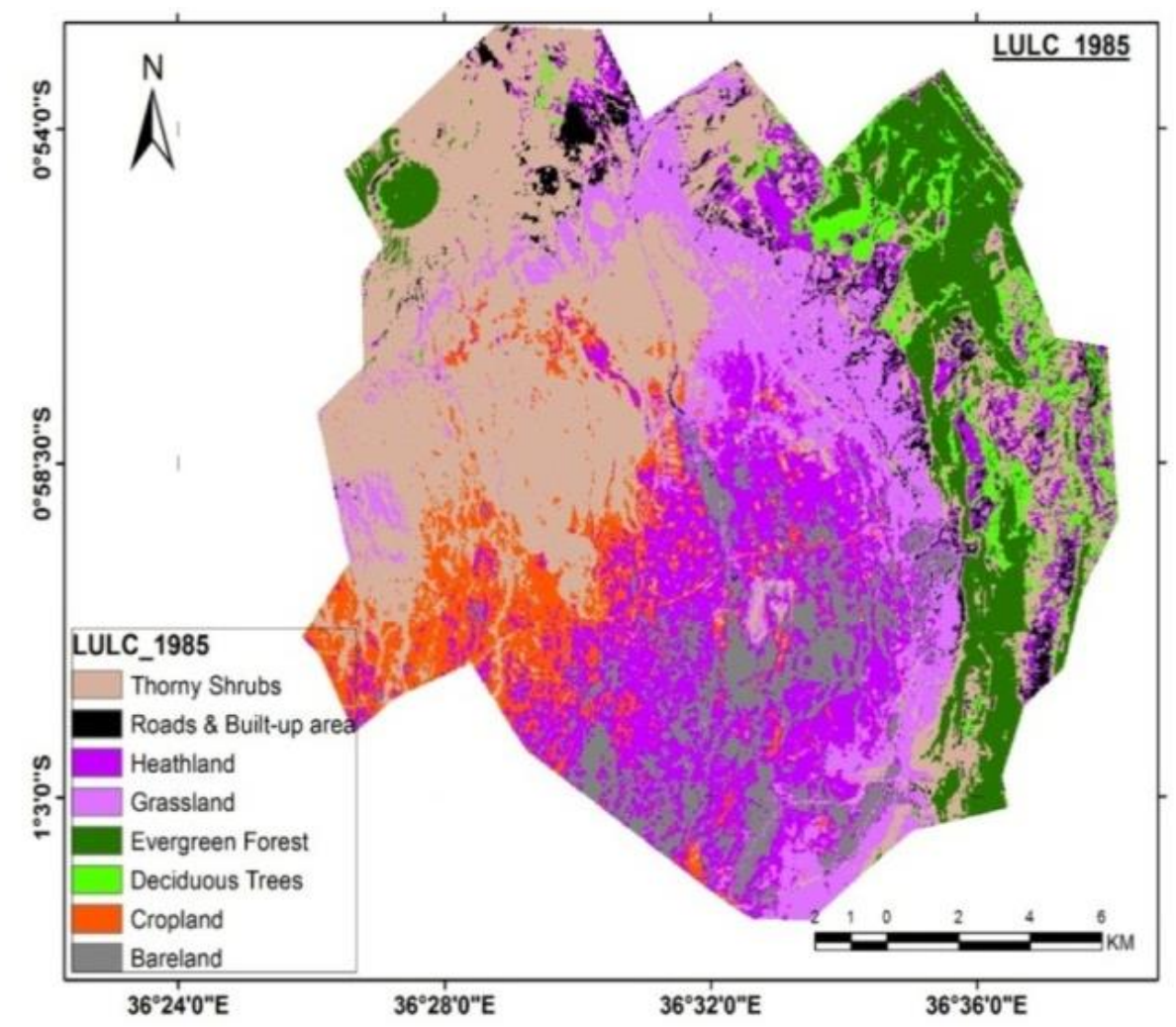

Figure 2. Satellite image on land-use and land-cover in Mai Mahiu in 1985.

The year 2000, the study area showed equal-area coverage of cropland and thorny shrubs (22\%). The bare-land covered an area of $53.7 \mathrm{~km}^{2}$ which is $15 \%$ while the grassland coverage was $35.1 \mathrm{~km}^{2}(10 \%)$. The evergreen trees covered $28.2 \mathrm{~km}^{2}(8 \%)$ while the roads and built-up area was $6 \%\left(19.9 \mathrm{~km}^{2}\right)$. Land-use and land-cover clusters were almost equally distributed as shown in the map below (Fig. 3). The land covered with grassland and heathlands were 
almost equal in size (10\%) while the minimal land coverage is observed with built-up areas and deciduous trees. The cropland extends from north to south was widely distributed areas. During this year the population in the area was likely to have increased that why we can observe more land being used as cropland.

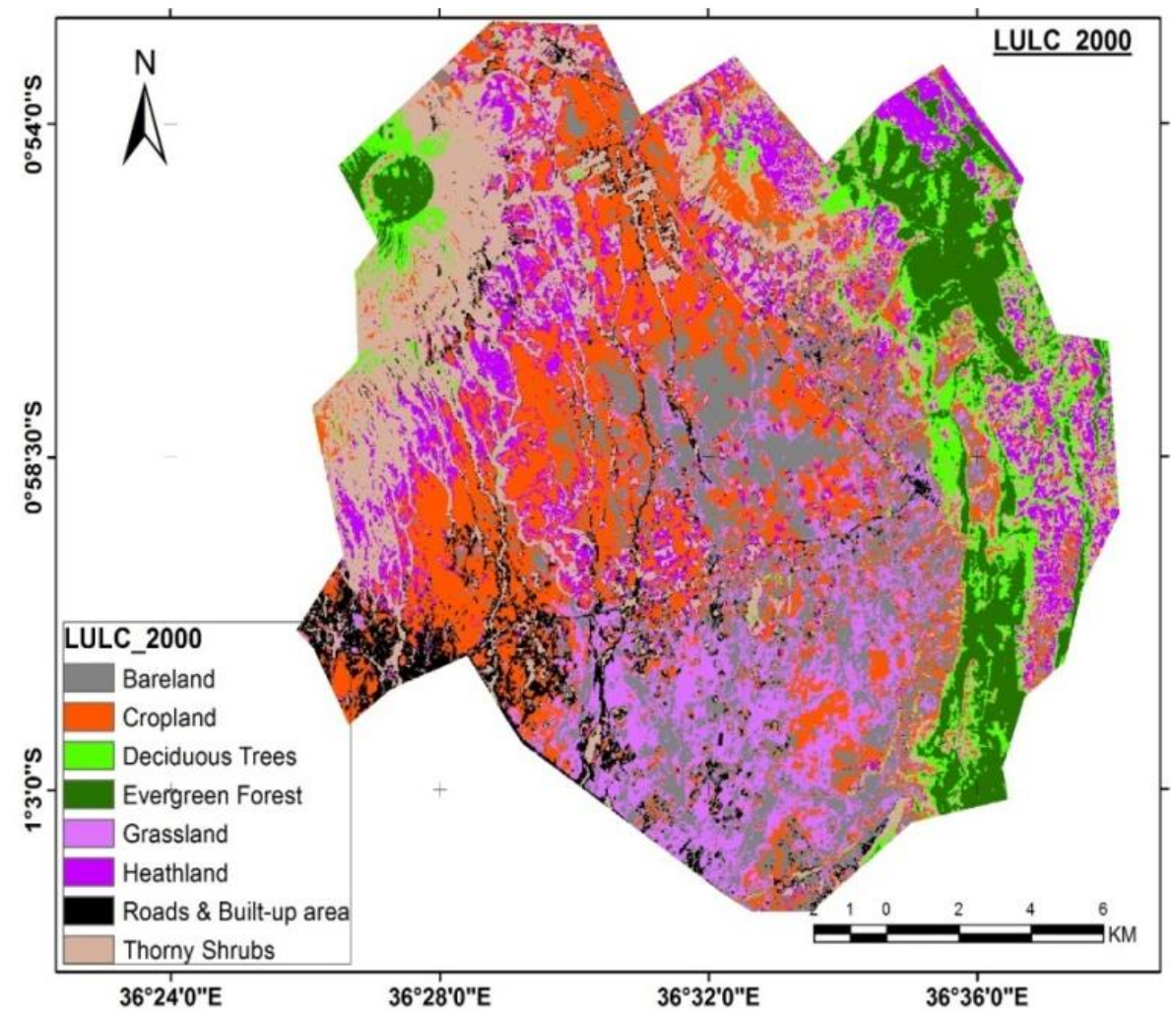

Figure 3. Satellite image on land-use and land-cover in Mai Mahiu in 2000.

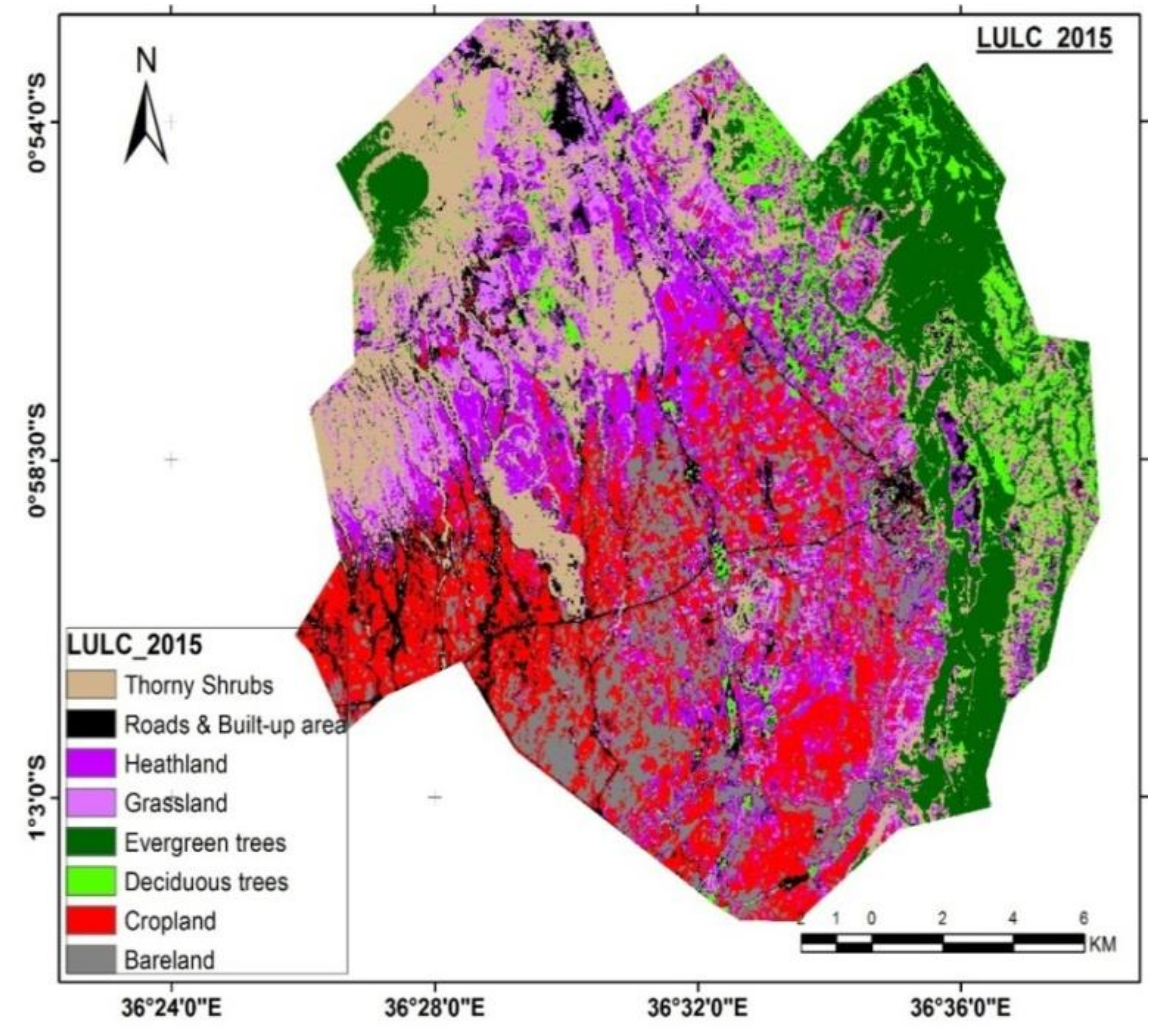

Figure 4. Satellite image on land-use and land-cover in Mai Mahiu in 2015.

In the year 2015, the land-use and land-cover map shows a decrease in the active cropland which covered $64.2 \mathrm{~km}^{2}$ $(18 \%)$ and an increase in the heathland covering $54.8 \mathrm{~km}^{2}(15 \%)$. The built-up area and the bare-land covered an area of $29.9 \mathrm{~km}^{2}$ and $34.1 \mathrm{~km}^{2}$ respectively. The increase in the heathland is attributed to the decrease in the active cropland. 
The coverage of the shrubs and cropland was relatively equal while the minimal land coverage was observed on the areas with deciduous trees, grassland and built-up area (Fig. 4).

The evergreen trees and deciduous trees are well observed on the eastern margin of the area which is approximately $16 \%$ of land in the study area (Table 2). The heathland and cropland are observed mainly within the central region of the study area. Mt. Longonot which lies at the northwestern part of the area is dominated by the evergreen trees especially at with the dormant crater area and thorny shrubs on the hillslopes. The built-up area and the exposed soils are observed in dark patches in the map.

\section{Land-use and land-cover change detection for the period 1985-2015}

The land-use and land-cover clusters that showed significant changes are highlighted in the table whereby the decreased coverage as indicated with negative value while the increased coverage is indicated with a positive value (Table 3). For example, the cropland shows a significant increase from $27.3 \mathrm{~km}^{2}$ to $79.6 \mathrm{~km}^{2}$ between 1985 and 2000. In the same year, the area used as a built-up area and roads in 2000 was almost double the same type of LULC in 1985 with a $104 \%$ increase. The bare land increased by $85 \%$ between 1985 and 2000. In 2015, the evergreen trees showed a tremendous increase of $73 \%$ from 1985.

The heathland increased by almost half (45\%) between 2000 and 2015 . This observation was corresponding to the decrease of the bare-land by $-19.7 \mathrm{~km}^{2}(-37 \%)$ in the same period. In 15 years the land used as built-up area and roads coverage had increased by almost three times from $9.8 \mathrm{~km}^{2}$ to $29.9 \mathrm{~km}^{2}$ between 1985 and 2015. The cropland significantly increased by $135 \%$ covering an area of 27.3 in 1985 and $64.2 \mathrm{~km}^{2}$ in 2015 respectively.

Table 3. Land-use and land-cover change detection for the period 1985-2015.

\begin{tabular}{lrrrrrrrrr}
\hline Land use/cover type & $\mathbf{1 9 8 5}$ & $\mathbf{2 0 0 0}$ & \% change & $\mathbf{2 0 0 0}$ & $\mathbf{2 0 1 5}$ & \% change & $\mathbf{1 9 8 5}$ & $\mathbf{2 0 1 5}$ & \% change \\
\hline Deciduous trees & 15.7 & 20.9 & $33 \%$ & 20.9 & 25.3 & $21 \%$ & 15.7 & 25.3 & $61 \%$ \\
Grassland & 49.6 & 35.1 & $-29 \%$ & 35.1 & 30.9 & $-12 \%$ & 49.6 & 30.9 & $-38 \%$ \\
Bare-land & 29.0 & 53.7 & $85 \%$ & 53.7 & 34.1 & $-37 \%$ & 29.0 & 34.1 & $17 \%$ \\
Roads/Built-up/soils & 9.8 & 19.9 & $104 \%$ & 19.9 & 29.9 & $50 \%$ & 9.8 & 29.9 & $206 \%$ \\
Evergreen Trees & 35.0 & 28.2 & $-19 \%$ & 28.2 & 48.8 & $73 \%$ & 35.0 & 48.8 & $39 \%$ \\
Thorny Shrubs & 120.3 & 79.6 & $-34 \%$ & 79.6 & 67.0 & $-16 \%$ & 120.3 & 67.0 & $-44 \%$ \\
Heathland & 68.2 & 37.9 & $-45 \%$ & 37.9 & 54.8 & $45 \%$ & 68.2 & 54.8 & $-20 \%$ \\
Cropland & 27.3 & 79.6 & $192 \%$ & 79.6 & 64.2 & $-19 \%$ & 27.3 & 64.2 & $135 \%$ \\
\hline \multicolumn{1}{c}{ Grand Total } & $\mathbf{3 5 4 . 9}$ & $\mathbf{3 5 4 . 9}$ & $\mathbf{0 \%}$ & $\mathbf{3 5 4 . 9}$ & $\mathbf{3 5 4 . 9}$ & $\mathbf{0 \%}$ & $\mathbf{3 5 4 . 9}$ & $\mathbf{3 5 4 . 9}$ & $\mathbf{0 \%}$ \\
\hline
\end{tabular}

For about 30 years period (1985-2015) significant land use and land cover changes were observed as highlighted in Table 4. During that period $0.6 \mathrm{~km}^{2}$ which was covered with deciduous trees in 1985 was used as a built-up area in 2015. Other changes show that $5.1 \mathrm{~km}^{2}$ of grassland, $2.2 \mathrm{~km}^{2}$ of bare land, $0.1 \mathrm{~km}^{2}$ of evergreen trees, $11.9 \mathrm{~km}$ of shrubs and $4.1 \mathrm{~km}^{2}$ of heathland were all converted to built-up areas in 2015. Shrubs land was cleared and resulted to $15.8 \mathrm{~km}^{2}$ of grassland, $17.7 \mathrm{~km}^{2}$ turned to be heathland and $7.8 \mathrm{~km}^{2}$ used as cropland in 2015 . The evergreen trees seem less disturbed but the shrubland was the most affected and cleared to pave way for settlements, cropland and other parts left as bare-land among other changes.

Table 4. Land use change between 1985-2015 in Mai Mahiu.

\begin{tabular}{|c|c|c|c|c|c|c|c|c|c|}
\hline \multicolumn{10}{|l|}{ LULC $2015\left(\mathrm{~km}^{2}\right)$} \\
\hline & $\begin{array}{r}\text { Deciduous } \\
\text { trees }\end{array}$ & $\begin{array}{l}\text { Grass- } \\
\text { land }\end{array}$ & $\begin{array}{l}\text { Bare- } \\
\text { land }\end{array}$ & $\begin{array}{r}\text { Roads/ Built- } \\
\text { up \& soils }\end{array}$ & $\begin{array}{r}\text { Evergreen } \\
\text { trees }\end{array}$ & $\begin{array}{l}\text { Thorny } \\
\text { Shrubs }\end{array}$ & Heathland & Cropland & $\begin{array}{r}\text { Grand } \\
\text { Total }\end{array}$ \\
\hline Deciduous trees & 5.0 & 0.2 & 0.0 & 0.6 & 5.8 & 2.8 & 1.1 & 0.1 & 15.7 \\
\hline Grassland & 3.7 & 7.1 & 4.2 & 5.1 & 0.3 & 4.3 & 14.5 & 10.4 & 49.6 \\
\hline is Bare-land & 0.9 & 1.6 & 10.3 & 2.2 & 0.0 & 0.3 & 6.3 & 7.3 & 29.0 \\
\hline$\stackrel{\circ}{2}$ Roads/Built-up/soils & 1.7 & 1.6 & 0.2 & 1.9 & 0.4 & 1.5 & 2.2 & 0.2 & 9.8 \\
\hline$\circlearrowright$ Evergreen Trees & 1.9 & 0.0 & 0.0 & 0.1 & 31.3 & 1.4 & 0.1 & 0.0 & 35.0 \\
\hline Thorny Shrubs & 6.0 & 15.8 & 1.0 & 11.9 & 9.4 & 50.9 & 17.7 & 7.8 & 120.3 \\
\hline Heathland & 5.7 & 3.8 & 15.0 & 4.1 & 1.6 & 4.6 & 10.7 & 22.8 & 68.2 \\
\hline Cropland & 0.3 & 0.8 & 3.3 & 3.9 & 0.0 & 1.2 & 2.2 & 15.5 & 27.3 \\
\hline Grand Total & 25.3 & 30.9 & 34.1 & 29.9 & 48.8 & 67.0 & 54.8 & 64.2 & 354.9 \\
\hline
\end{tabular}

Land-use changes especially in the developing world are caused by agricultural expansion and deforestation (Geist \& Lambin, 2002; Alejandro et al., 2007; Kathumo, 2011). The observed changes in land-use/cover can be associated with rapid population growth that had significantly increased in the area since the 1990s. This led to unsustainable land and resource utilization including deforestation, agricultural expansion and other land-use conversions to satisfy various needs. Poor agricultural activities have led to the abandonment of land cultivation for other economically viable practices such as sand harvesting and quarrying that are on high demand in the nearby commercial towns of Naivasha, 
Nairobi and Narok. Drigo (2005) notes that population growth and density as main factors that lead to clearing the forest area for agricultural activities in a given region.

\section{Changes on soil properties}

Bulk density increased with land-use change and ranged between $0.93 \mathrm{~g} \mathrm{~cm}^{-3}$ and $1.27 \mathrm{~g} \mathrm{~cm}^{-3}$. Lower bulk density values of $0.93 \mathrm{~g} \mathrm{~cm}^{-3}$ were recorded in undisturbed forest soil compared to intermediate values of $1.07 \mathrm{~g} \mathrm{~cm}^{-3}$ and $1.16 \mathrm{~g}$ $\mathrm{cm}^{-3}$ in the disturbed forest where Croton spp. and Tarchonanthus camphoratus L. were dominant vegetation, respectively. Cultivated and severely grazed fields recorded higher values of $1.23 \mathrm{~g} \mathrm{~cm}^{-3}$ and $1.27 \mathrm{~g} \mathrm{~cm}^{-3}$, respectively (Table 5). The increase in bulk density with disturbance ranged between 12 and $25 \%$. The values were statistically different $(\mathrm{p}<0.001)$ across land-use and land-cover types. Bulk density is an important soil physical index that tells about the state of soil structure and state and transport of matter including water movement and storage, aeration and thermal conductivity in the soil system. This index is promoted by soil aggregation which is influenced by soil organic matter, microorganism activity and their by-products, inorganic substances and soil management (Weil \& Brady, 2017). The causes of the increase in bulk density in the study area were attributed to the deterioration of soil structure due to loss of soil organic matter, soil compaction, loss of vegetation cover, poor tillage/cultivation practices and overgrazing. It is noted that deforestation and poor tillage practices for can increase bulk density by 20\% (Hajabbasi et al., 1997) thereby affecting hydraulic conductivity and water transmission in the soil (Biro et al., 2013).

Table 5. Mean comparison of soil physical and chemical properties under different land-use and land-cover practices within Mai Mahiu study area.

\begin{tabular}{lrrrrrr}
\hline Soil parameter & \multicolumn{7}{c}{ Land-use and Land-cover practices } \\
\cline { 2 - 7 } & $\begin{array}{r}\text { Undisturbed } \\
\text { forest }\end{array}$ & $\begin{array}{r}\text { Disturbed } \\
\text { forest (Croton- } \\
\text { dominated) }\end{array}$ & $\begin{array}{r}\text { Disturbed forest } \\
\text { (Tarchonanthus- } \\
\text { dominated) }\end{array}$ & Cropland & $\begin{array}{r}\text { Disturbed } \\
\text { grassland }\end{array}$ & p-value \\
\hline Bulk density & $0.93 \pm 0.02^{\mathrm{a}}$ & $1.07 \pm 0.04^{\mathrm{b}}$ & $1.16 \pm 0.01^{\mathrm{bc}}$ & $1.23 \pm 0.03^{\mathrm{c}}$ & $1.27 \pm 0.02^{\mathrm{c}}$ & $<0.001$ \\
$\mathrm{pH}$ & $7.18 \pm 0.12^{\mathrm{c}}$ & $7.09 \pm 0.18^{\mathrm{bc}}$ & $6.82 \pm 0.12^{\mathrm{bc}}$ & $6.51 \pm 0.08^{\mathrm{ab}}$ & $6.19 \pm 0.14^{\mathrm{a}}$ & 0.002 \\
Total N (\%) & $0.34 \pm 0.06^{\mathrm{b}}$ & $0.33 \pm 0.02^{\mathrm{b}}$ & $0.27 \pm 0.04^{\mathrm{ab}}$ & $0.17 \pm 0.01^{\mathrm{a}}$ & $0.15 \pm 0.01^{\mathrm{a}}$ & 0.005 \\
Total SOC (\%) & $3.55 \pm 0.58^{\mathrm{b}}$ & $3.47 \pm 0.32^{\mathrm{b}}$ & $2.65 \pm 0.37^{\mathrm{ab}}$ & $1.79 \pm 0.23^{\mathrm{a}}$ & $1.59 \pm 0.12^{\mathrm{a}}$ & 0.008 \\
C/N ratio & $10.33 \pm 0.01^{\mathrm{a}}$ & $10.37 \pm 0.45^{\mathrm{a}}$ & $10.05 \pm 0.31^{\mathrm{a}}$ & $10.44 \pm 0.79^{\mathrm{a}}$ & $10.61 \pm 0.08^{\mathrm{a}}$ & 0.919 \\
\hline
\end{tabular}

Note: Alphabets a, b, c same letter indicates no statistical difference at $\mathrm{p}<0.05$.

Soil pH decreased with disturbance and ranged between 7.18 and 6.19 across land-use practices. Mean pH values were 7.18 in undisturbed forest, 7.09 in the croton-dominated field while soils from Tarchonanthus camphoranthus vegetation, cropland and disturbed grassland fields recorded lower average values of 6.82, 6.51 and 6.19, respectively. Analysis of variance showed a significant difference $(\mathrm{p}=0.002)$ in $\mathrm{pH}$ values across land-use practices. Soil $\mathrm{pH}$ is a general indicator and integrator of the nutrient release environment and soil contamination (Weil \& Brady, 2017). Higher $\mathrm{pH}$ value in the forest and croton-dominated soils was attributed to a higher amount of debris and organic matter in these soils compared to lower values in Tarchonanthus camphoranthus-dominated soils which may be attributed to a high concentration of acidic elements in floral parts which, upon abscission and decomposition, they decrease soil $\mathrm{pH}$. On the other hand, low $\mathrm{pH}$ values in cropland and severely grazed field is because of loss of basic cations through soil erosion and nutrient mining through crop harvesting without return of organic materials into the soil. Another possible explanation could be the use of acidic fertilizers such as diammonium phosphate and calcium ammonium nitrate which have increased hydrogen ion concentration in the cropland.

Soil organic carbon concentration was high in undisturbed forest soil $(3.55 \%)$ followed by disturbed forest where Croton spp dominating (3.47\%), a disturbed forest where Tarchonanthus camphoranthus is dominating (2.65\%), cropland (1.79\%) and disturbed grassland (1.59\%). Conversion of the forest led to a $63 \%$ SOC loss in disturbed grassland, $57 \%$ in cultivated fields, $35 \%$ in Tarchonanthus camphoranthus-dominated vegetation and $17 \%$ in crotondominated vegetation. There was a significant difference in soil organic carbon concentrations $(\mathrm{p}=0.001)$ across landuse practices. Total nitrogen concentrations varied widely across land-use practices. There was a significant difference $(\mathrm{p}=0.005)$ in these values across land-use/cover practices with forest soils recording higher mean value of $0.34 \%$ followed by $0.33 \%$ in croton-dominated and $0.27 \%$ in Tarchonanthus camphoranthus-dominated soils. N losses observed in disturbed grassland and cultivated soils fields represented 55.9 and $50.0 \%$ of the original stock respectively. Soil organic carbon (SOC) is vital for enhancing and promoting soil fertility for agricultural production that is sustainable and carbon storage and climate change resilience (Luo et al., 2019). Soil organic carbon and nitrogen are key indicators used in assessing soil productivity in different land uses and management. The decrease in $\mathrm{C}$ and $\mathrm{N}$ with land-use changes notably in severely grazed and cropland and Tarchonanthus camphoranthus-dominated fields is a manifestation of a degraded ecosystem. Land-use and land-cover modifications have enhanced SOC depletion through various mechanisms including oxidation/decomposition and biological mineralization and exposure of occluded organic 
carbon through tillage practices, reduction in the input of organic materials or residues and erosional losses in cultivated soils and disturbed grassland. The poor land-use practice has led to land degradation consequently affecting soil health through depletion of soil organic matter, nutrients and erosion (Six et al., 1999; Lal, 2003; Solomon et al., 2007). Landuse and land-cover changes can lead to losses of up to $58 \%$ of the initial SOC pools especially in the tropical soils that store $32 \%$ of global soil C stocks (Basweti, 2009; Bonilla-Bedoya et al., 2017).

Carbon:Nitrogen $(\mathrm{C}: \mathrm{N})$ ratio had no significant difference $(\mathrm{p}=0.919)$ across land-use/cover change with mean values ranging between 10.05 and 10.61 . There was a positive correlation $(r=0.978)$ between carbon and nitrogen. Lack of statistical significance in Carbon:Nitrogen $(\mathrm{C}: \mathrm{N})$ ratio is attributed to similar SOC and $\mathrm{N}$ loss kinetics that lead to a positive correlation between the losses of SOC and $\mathrm{N}$ with time. $\mathrm{C} / \mathrm{N}$ ratios were similar to average values reported for agricultural soils by Solomon et al. (2007).

\section{CONCLUSION}

It is concluded that significant land-use/cover change has taken place in Mai Mahiu ecosystem that has resulted in drastic changes in soil properties. If unchecked, it can lead to loss of productivity of and economic opportunities from this ecosystem. Disturbance-induced land/vegetation cover changes can be used as a general outlook of the nature of soil conditions in the disturbed and degraded tropical ecosystems.

\section{ACKNOWLEDGEMENTS}

We appreciate the help of Mr Stephen Gichugu Muturi for information on local knowledge about land use practices in the study area. I am thankful to the technical staff led by Benjamin of Environmental Sciences Laboratory, Kenyatta University for the support in laboratory analysis.

\section{REFERENCES}

Alejandro F.S., Ramos M.M. \& Masera O.R. (2007). Assessing implications of land-use and land-cover change dynamics for forest conservation of a highly diverse tropical rain forest. Biological Conservation, 138: 131-145.

Anil N., Sankar G., Rao M. \& Sailaja U. (2011). Studies on land use/land cover and change detection from parts of South West Godavari District, A.P - using Remote Sensing and GIS techniques. Journal of Indian Geophysical Union, 15(4): 187-194.

Bahn M., Knap M., Garajova Z., Pfahringer N. \& Cernusca A. (2006). Root respiration in temperate mountain grasslands differing in land use. Global Change Biology, 12: 995-1006.

Basweti C.N. (2009). Influence of organic matter quality on responses of soil organic matter decomposition to variation in soil temperature and moisture, (M.Sc. Thesis). University of Nairobi, Kenya.

Bationo A., Kimetu J., Ikeera S., Kimani S., Mugendi D., Odendo M., Silver M., Swift M.J. \& Sanginga N. (2004). The African Network for soil biology and fertility: new challenges and opportunities. In: Bationo A. (Ed.) Managing nutrient cycles to sustain soil fertility in sub-Saharan Africa. Academy Science Publishers and TSBF, pp. 1-23.

Biro K., Pradhan B., Buchroithner M. \& Makeschi F. (2013). Land use/land cover change analysis and its impact on soil properties in the northern part of Gadarif region, Sudan. Land Degradation \& Development, 24(1): 90-102.

Black C.A. (Ed.) (1965). Methods of soil analysis, Part 2, Chemical and Microbiological Properties. American Society of Agronomy, Inc., Madison, Wis.

Blake G.R. (1965). Bulk Density. In: Black C.A. (Ed.) Methods of Soil Analysis, (Agronomy, No. 9, Part 1). Soil Science of America and American Society of Agronomy, Madison-USA. pp. 374-390.

Bonilla-Bedoya S., López-Ulloa M., Vanwalleghem T., Herrera-Machuca \& Miguel Á. (2017). Effects of Land Use Change on Soil Quality Indicators in Forest Landscapes of the Western Amazon. Soil Science, 182(4): 128-136.

Bouyoucous G.J.A. (1951). Recalibration of the hydrometer for making mechanical analysis of soil. Agronomy Journal, 43: 434-438.

Braimoh A.K. \& Osaki M. (2010). Land-use change and environmental sustainability. Sustainability Science, 5: 5-7.

Bremner J.M. (1996). Methods of Soil Analysis, Part 3. Chemical Methods. Soil Science of America and American Society of Agronomy, SSSA Book Series No. 5, Madison-USA.

Drigo R. (2005). Trends and patterns of tropical land use change. In Bonell M. \& Bruijnzeel L. (Eds.) Forests, Water and People in the Humid Tropics: Past, Present and Future Hydrological Research for Integrated Land and Water Management (International Hydrology Series). Cambridge University Press, Cambridge, pp. 9-39. [DOI:10.1017/CBO9780511535666.006]

Ellis E. (2010). Land-use and land-cover change. The Encyclopedia of Earth. Retrieved from: http://www.eoearth.org/view/ article/154143/

FAO (2015). Global Forest Resources Assessment (2015). Food and Agriculture Organization of the United Nations (FAO), Rome, Italy.

Geist H.J. \& Lambin E.F. (2002). Proximate causes and underlying driving forces of tropical deforestation. BioScience, 52(2): 14350.

Hajabbasi M.A., Jalalian A. \& Karimzadeh H.R. (1997). Deforestation effects on soil physical and chemical properties, Lordegan, Iran. Journal of Plant and Soil, 190(2): 301-308. 
IPCC (2018). Summary for Policymakers. In: Masson-Delmotte V., Zhai P., Pörtner H.O., Roberts D., Skea J., Shukla P.R., Pirani A., Moufouma-Okia W., Péan C., Pidcock R., Connors S., Matthews J.B.R., Chen Y., Zhou X., Gomis M.I., Lonnoy E., Maycock T., Tignor M. \& Waterfield T. (Eds.) Global warming of $1.5^{\circ} \mathrm{C}$. An IPCC Special Report on the impacts of global warming of $1.5^{\circ} \mathrm{C}$ above pre-industrial levels and related global greenhouse gas emission pathways, in the context of strengthening the global response to the threat of climate change, sustainable development, and efforts to eradicate poverty. World Meteorological Organization, Geneva, Switzerland, $32 \mathrm{p}$.

Kathumo V.M. (2011). Application of remote sensing and GIS in assessing land use and land cover changes and their impact on hydrological regime in river Gucha catchment, Kenya, (Ph.D. Thesis). Department of Land Resource Management and Agricultural Technology, University of Nairobi, Kenya.

Keesstra S.D., Bouma J., Wallinga J., Tittonell P., Smith P., Cerdà A., Montanarella L., Quinton J.N., Pachepsky Y., van der Putten W.H., Bardgett R.D., Moolenaar S., Mol G., Jansen B. \& Fresco L.O. (2016). The significance of soils and soil science towards realization of the United Nations Sustainable Development Goals. Soil, 2: 111-128.

Lal R. (2003). Global potential of soil carbon sequestration to mitigate the greenhouse effect. Crit. Rev. Plant Science, 22: 151-184.

Lambin E. \& Geist H. (2007). Causes of land-use and land-cover change. The Encyclopedia of Earth. Retrieved from: http://www.eoearth.org/view/article/150964/

Lambin E., Geist H. \& Rindfuss R. (2006). Introduction: local process with global impact. In Lambin E. \& Geist H. (Eds.) Land-use land cover change: local process global impacts. New York: Springer, pp. 1-8.

Luo Z., Eady S., Sharma B., Grant T., Liu L., Cowie A., Farquharson R., Simmons A., Crawford D., Searle R. \& Moore A. (2019). Mapping future soil carbon change and its uncertainty in croplands using simple surrogates of a complex farming system model. Geoderma, 314: 311-321.

Onur I., Maktav D., Sari M. \& Sönmez N.K. (2009). Change detection of land cover and land use using remote sensing and GIS: A case study in Kemer, Turkey. International Journal of Remote Sensing, 30: 1749-1757.

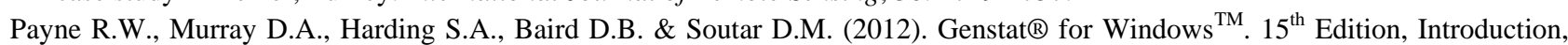
VSN International, Oxford.

Rhoades J.D. (1996). Salinity: Electrical conductivity and total dissolved solids. In: Sparks D.L. (Ed.) Methods of soil analysis, Part 3. Chemical methods. SSSA Book Ser. 5. SSSA, Madison, WI, pp. 417-435.

Ries JB. (2010). Methodological for soil erosion and land degradation assessment in Mediterranean type ecosystems. Land Degradation \& Development, 21: 171-187.

Six J., Elliott E.T. \& Paustian K. (1999). Aggregate and Soil Organic Matter Dynamics under Conventional and No-Tillage Systems. Soil Science Society of America Journal, 63: 1350-1358.

Solomon D., Lehmann J., Kinyangi J., Amerung W., Lobe I., Pell A., Riha S., Ngoze S., Verchot L., Mbugua D., Skjemstad J. \& Schäfer T. (2007). Long-term impacts of anthropogenic perturbations on dynamics and speciation of organic carbon in tropical forest and subtropical grassland ecosystems. Global Change Biology, 13: 1-20.

Symeonakis E., Calvo-Cases A. \& Arnau-Rosalen E. (2007). Land use change and land degradation in Southeastern Mediterranean Spain. Environ Manage, 40: 80-94.

Weil R.R. \& Brady N.C. (2017). The Nature and Properties of Soils, $15^{\text {th }}$ Edition. Pearson Press, Upper Saddle River NJ, USA. 